\title{
Peran Guru dan Perilaku Etis Murid Taman Kanak-Kanak
}

\author{
Chitra Lestari \\ Institut Komunikasi dan Bisnis LSPR, Jakarta, Indonesia
}

\begin{abstract}
ABSTRAK
Penelitian ini membahas mengenai peran guru membangun perilaku etis dalam komunikasi interpersonal pada murid TK Mini Pak Kasur Cikini. Tujuan penelitian ini untuk mengetahui peran guru membangun perilaku etis melalui komunikasi interpersonal pada murid TK Mini Pak Kasur Cikini. Teori utama yang digunakan adalah teori komunikasi yang dikemukan oleh David K.Berlo yang berfokus pada komunikasi interpersonal. Metode yang digunakan dalam penelitian ini adalah metode penelitian kualitatif dengan wawancara mendalam terhadap lima informan. Melalui display data, reduksi data dan penyusunan kesimpulan. Penelitian ini menghasilkan kesimpulan bahwa peran guru sangat mempengaruhi murid dalam berperilaku etis. Perubahan perilaku pada murid dapat dilihat pada komunikasi interpersonal antara guru dan murid yang terjalin dengan efektif.
\end{abstract}

Kata kunci: guru; peran; etika; perilaku; komunikasi interpersonal

\begin{abstract}
This research will discuss the role of the teacher in building ethical behavior of the students in interpersonal communication on TK Mini Pak Kasur Cikini. The purpose of this research is to identify the role of the teacher to build ethical behavior of students in interpersonal communication on TK Mini Pak Kasur Cikini. The main theory of this research is communication theory stated by David K.Berlo which focuses on interpersonal communication. The method used in this research is qualitative with indepth interview to five informants. The data analysis consists of data reduction, data display and conclusion. The results of this research are to show the role of the teacher affected students in behaving ethically. This is proven by the behavioral changes on students that can be seen from the interpersonal communication between teachers and students are run effectively.
\end{abstract}

Keywords: teacher; role; ethical; behavior; interpersonal communication

\section{PENDAHULUAN}

Pada era modern sekarang ini banyak krisis yang melanda kehidupan manusia contohnya kekhawatiran akan moralitas manusia zaman sekarang ini. Karena menanamkan perbuatan baik. dan positif pada seseorang bukanlah hal mudah dan dapat diajarkan secara dadakan. Untuk mengantisipasinya maka perlu di bangun perilaku etis pada anak sejak dini oleh guru di sekolah yang notabennya sebagai salah satu lembaga pendidikan kedua setelah keluarga. Perilaku etis di sini yaitu bagaimana anak yang masih pada usia dini ini mampu menghormati orang yang lebih tua, menghormati lambang negaranya, berperilaku sopan, berbicara yang santun, berpakaian yang sopan, membuang sampah pada tempatnya, berkarakter positif serta 
mampu bergaul dengan baik di lingkungannya.

Perilaku etis merupakan inti dari etika, etis berarti sesuai dengan aturan atau standar perilaku yang benar oleh karena itu perilaku etis perlu ditanamkan sejak dini untuk membentuk karakter yang santun dan sopan pada anak. Tujuannya untuk membiasakan anak bertindak sopan dan ramah kepada siapa saja, lalu agar mereka dapat menjaga dan menghargai perasaan orang lain dan tidak mementingkan dirinya sendiri serta perilaku etis juga menuntun mereka bagaimana harus bergaul di dalam masyarakat dan lingkungannya.

Ranah penelitian ini adalah relasi antara guru dan murid dalam pembentukan perilaku maka komunikasi menjadi penting sebagai sarana pembentukan perilaku etis. Adapun pola komunikasi yang dilakukan antara guru dan murid pada penelitian ini yakni pola komunikasi yang terjadi antar pribadi atau Interpersonal Communication. Komunikasi antar pribadi adalah komunikasi antara orang-orang secara tatap muka, yang memungkinkan setiap pesertanya menangkap reaksi orang lain secara langsung, baik secara verbal maupun nonverbal dan hanya melibatkan dua orang (Mulyana, 2012, p.81).

Pada penelitian ini tujuan komunikasi interpersonal berorientasi pada mempengaruhi sikap dan tingkah laku. Melalui peranan komunikasi interpersonal diharapkan guru mampu mengubah sikap dan perilaku muridnya agar memiliki perilaku etis. Dengan adanya pemberian makna dalam penyampaian informasi dan pengetahuan tertentu dari pengirim pesan, akan memungkinkan terjadinya perubahan sikap pada diri si penerima pesan tersebut.

Penelitian ini berfokus di TK Mini Pak Kasur Cikini. TK Mini Pak Kasur adalah Taman Kanakkanak yang didirikan sejak tahun 1953 oleh Pak Kasur yang terletak di Jalan Cikini V No.3 Menteng, Jakarta Pusat. Pak Kasur sendiri ialah seorang Tokoh Pendidikan Anak dan pencipta lagu anak-anak. Kegiatan belajar mengajar di TK Mini Pak Kasur ini mengikuti Kurikulum Nasional yang didukung oleh sistem pendidikan "ala" Pak Kasur yaitu melalui nyanyian yang sarat dengan unsur pendidikan, bernuansa gembira sehingga mudah dipelajari anak-anak dan alat peraga edukatif yang diciptakan sendiri oleh Pak Kasur dengan tujuan mengembangkan kreativitas dan potensi anak sejak dini.

Selain itu dari sebuah artikel yang dimuat oleh salah satu institusi media online, kapanlagi.com, peneliti menemukan bahwa Taman Kanak-kanak (TK) Mini Pak Kasur Cikini menduduki peringkat ketiga untuk taman kanak-kanak atau sekolah playgroup favorit di wilayah Jakarta Pusat. Jika telah dikatakan favorit, dapat diartikan bahwa para orang tua lebih suka dan mempercayakan tempat pendidikan formal untuk anaknya di TK Mini Pak Kasur ini. Peneliti juga telah melakukan pra-riset dengan bertanya kepada sejumlah orang dan hasilnya anak-anak lulusan TK Mini Pak Kasur Cikini memiliki perilaku etis yang positif.

Karena masalah tersebut peneliti tertarik untuk menelitinya dengan mengajukan pertanyaan "Bagaimana Peran Guru Membangun Perilaku Etis Dalam Komunikasi Interpersonal Pada Murid TK Mini Pak Kasur Cikini?”. Tujuan peneliti dalam penelitian ini adalah untuk mengetahui peran guru membangun perilaku etis dalam komunikasi interpersonal pada murid 


\section{TK Mini Pak Kasur Cikini.}

Adapun manfaat dari penelitian ini adalah diharapkan hasil dari penelitian ini dapat memberi saran yang berguna untuk seluruh guru TK Mini Pak Kasur Cikini dalam membangun komunikasi interpersonal dengan murid, selain itu dapat meningkatkan pengetahuan tentang peran guru membangun perilaku etis dalam komunikasi interpersonal pada murid dan dapat menjadi bahan diskusi serta pertimbangan bagi peneliti lain yang memiliki topik yang sama.

Teori komunikasi yang dikemukakan oleh David K. Berlo menjadi acuan dalam penelitian ini. Model komunikasi Berlo yakni model SMCR yang memiliki kepanjangan Source (sumber), Message (pesan), Channel (saluran) dan Receiver (penerima) (Mulyana, 2012, p.162). Dalam model komunikasi Berlo dapat diaplikasikan kepada pembahasan penelitian yakni, Source, Guru TK Mini Pak Kasur Cikini. Message, Pesan yang akan disampaikan kepada anak didiknya. Channel, alat peraga, gambar atau warna, permainan, nyanyian atau lagu, dongeng atau cerita dan sentuhan ataupun tatap muka sebagai saluran komunikasi yang digunakan dalam penyampaian pesan. Receiver, Murid TK Mini Pak Kasur Cikini.

\section{METODE PENELITIAN}

Penelitian ini menggunakan metode penelitian kualitatif. Metode penelitian kualitatif adalah metode penelitian yang digunakan untuk meneliti pada kondisi obyek alamiah, dimana peneliti adalah sebagai instrumen kunci, teknik pengumpulan data dilakukan secara trianggulasi atau gabungan, analisis data bersifat induktif dan hasil penelitian kualitatif lebih menekankan makna dari pada generalisasi (Sugiyono, 2015, p.1). Dalam penelitian ini yang akan diamati adalah interaksi antar individu, yakni guru dan murid pada TK Mini Pak Kasur Cikini. Guru di sini mempunyai tugas mendidik, membentuk karakter dan membangun perilaku etis pada anak muridnya. Interaksi antara guru dan murid itulah yang akan menghasilkan suatu situasi sosial tertentu. Situasi sosial itu sendiri terdiri atas tiga elemen yaitu: tempat (place), pelaku (actors) and aktivitas (activity). Pada situasi sosial tersebut peneliti dapat mengamati secara mendalam objek penelitian yang ingin diketahui.

Tujuan menggunakan metode ini adalah untuk dapat lebih memahami, menjelaskan serta memperoleh gambaran yang mendalam dan memiliki kredibilitas yang tinggi tentang bagaimana peran guru membangun perilaku etis dalam komunikasi interpersonal pada murid TK Mini Pak Kasur Cikini sehingga tujuan penelitian pun dapat dicapai. Pada penelitian ini terdapat beberapa informan yang dianggap menguasai dan memahami situasi sosial penelitian. Informan yang dapat dijadikan sumber data yakni kepala sekolah, pembina guru, guru dan orang tua murid TK Mini Pak Kasur Cikini. 


\section{HASIL DAN PEMBAHASAN}

\section{Komunikasi Interpersonal Antara Guru dan Murid TK Mini Pak Kasur Cikini}

Ditinjau dari prosesnya, pendidikan adalah komunikasi dalam arti kata bahwa dalam proses tersebut melibatkan dua komponen yang terdiri atas pengajar sebagai komunikator dan pelajar sebagai komunikan (Effendy, 2011, p.101). Komunikasi yang terjadi antara guru dan murid TK Mini Pak Kasur Cikini merupakan komunikasi interpersonal yang bertujuan untuk membangun perilaku etis pada murid. Biasanya komunikasi ini terjalin langsung di dalam kelas secara tatap muka (face to face). Proses komunikasi interpersonal yang terjadi antara guru dan murid adalah adanya keinginan berkomunikasi, disini guru memiliki keinginan untuk membangun perilaku etis pada muridnya.

Encoding oleh komunikator, guru memformulasikan pesan ke dalam simbol-simbol dan katakata, biasanya melalui cerita, nyanyian ataupun alat peraga. Kemudian pengiriman pesan, guru memilih saluran komunikasi secara tatap muka karena dianggap lebih efektif dalam penyampaian pesan. Setelah itu, penerimaan pesan, pesan yang disampaikan guru telah diterima oleh anak didiknya. Decoding oleh komunikan, ditahap ini anak berusaha memahami kata-kata dan simbol-simbol yang diberikan guru. Anak menerjemahkan pesan yang diterima dari guru dengan benar dan mampu memberi arti yang sama pada simbol-simbol sebagaimana yang diharapkan oleh guru tersebut. Dan terakhir umpan balik, setelah memahami maksud pesan tersebut, selanjutnya anak didik merespon apa yang guru sampaikan. Bentuk responnya itu dengan mempraktekan langsung apa yang diajarkan oleh guru. Dari proses komunikasi yang dijabarkan di atas peneliti menarik kesimpulan bahwa keefektifan komunikasi interpersonal antara guru dan murid TK Mini Pak Kasur Cikini dapat dilihat sebagaimana adanya respon yang diberikan anak didik setelah menerima dan memahami apa yang disampaikan oleh guru.

Menurut Devito (dalam Aw, 2011, p.82) terdapat lima sikap positif yang perlu dipertimbangkan ketika seseorang merencanakan komunikasi interpersonal yakni, pertama, keterbukaan (openness), keterbukaan di sini yang ingin peneliti ketahui adalah bagaimana guru menunjukan sikap terbuka kepada anak didiknya dalam komunikasi yang terjalin di antara keduanya. Karena sikap terbuka amat besar pengaruhnya dalam komunikasi interpersonal yang efektif. Sikap keterbukaan ditandai dengan adanya kejujuran dalam merespon segala stimuli komunikasi. Tidak berkata bohong dan tidak menyembunyikan informasi yang sebenarnya. Dengan keterbukaan maka komunikasi interpersonal akan berlangsung secara adil, transparan, dua arah dan dapat diterima oleh semua pihak yang berkomunikasi.

Kedua, empati (empathy) peneliti ingin mengetahui bagaimana sikap empati yang ditunjukan guru kepada anak didiknya sehingga memiliki kemampuan untuk merasakan apa yang dirasakan anak didiknya dan memahami suatu persoalan dari sudut pandang anak didik. Seperti yang disampaikan pembina guru TK Mini Pak Kasur Cikini adalah sikap empati yang ditunjukan dari guru sendiri adalah pada saat anak dalam kesulitan. Dengan naluri berempati dari guru tersebut maka guru dengan sabar membantu dan menolong anak yang sedang dalam kesulitan. Di TK Mini Pak Kasur Cikini sendiri, terdapat dua guru yang mengajar di dalam satu kelas. Hal tersebut memudahkan guru untuk melihat dan membantu serta menolong anak yang 
kesulitan dalam aktivitas KBM. Selain itu biasanya guru langsung menjenguk anak yang sedang sakit, merasakan apa yang anak tersebut rasakan. Memberikan semangat untuk anak tersebut agar lekas sembuh dan bisa bersekolah kembali. Atau memberitahu langsung kepada murid lain, kemudian bertanya siapa yang mau mendoakan temannya yang sedang sakit? Setelah itu baru kita berdoa bersama-sama dan mengajak murid lainnya ikut menjenguk anak yang sakit tersebut. Tujuannya untuk membangun rasa empati pula pada anak didik.

Ketiga, sikap mendukung (supportiveness) kepala sekolah TK Mini Pak Kasur Cikini menjelaskan bahwa bentuk dukungan yang diberikan guru kepada anak didik agar tercipta komunikasi yang efektif yaitu harus mampu mengambil hati anak dan selalu berusaha menjadi idola anak. Misalnya harus pandai berlucu agar bisa menjadi seusia anak-anak tersebut. Menjadi idola anak agar anak dengan sendirinya terpersuasi melakukan hal-hal baik dan positif seperti apa yang ibu guru lakukan. Tak hanya itu merespon hal-hal seperti dalam bermain games pastikan ya ada yang kalah dan ada yang menang, di sini peran guru mengajarkan kepada anak yang kalah untuk tidak berkecil hati dan memberi dukungan serta semangat agar bisa menang digames selanjutnya.

Keempat, sikap postif (positiveness) guru TK Mini Pak Kasur Cikini menjelaskan bahwa menghargai dan berusaha memahami anak dengan karakternya yang berbeda-beda. Selalu memberikan pujian dan penghargaan apabila anak berperilaku baik. Misalnya melalui sentuhan dan komunikasi non verbal, ketika saya melihat anak mengambil sampah yang jatuh di lantai dan anak tersebut langsung membuangnya ke tempat sampah maka saya menyentuh pundaknya dan mengacungkan jempol dan berkata "wah hebat kamu, selalu buang sampah pada tempatnya ya nak agar lingkungan selalu bersih dan sehat". Hal tersebut menunjukan bahwa guru memiliki sikap dan pikiran positif dalam berkomunikasi dengan anak didiknya. Memberikan pujian dan penghargaan dalam aktivitas nyata untuk terjalinnya kerja sama di antara keduanya.

Kelima, kesetaraan (equality) kepala sekolah TK Mini Pak Kasur Cikini mengatakan bahwa komunikasi, perlakuan dan bimbingan sama, hanya berbeda pada penyampaian pesan yang disesuaikan dengan karakter anak. Sebisa dan sepintar-pintarnya guru agar anak mampu mengikuti KBM dan mampu menerima isi pesan dengan baik. Begitu pula dengan komunikasi antara guru dan anak, guru berusaha memposisikan diri sebagai ibu dan teman agar tidak ditakuti dan disegani oleh anak. Menurut guru TK Mini Pak Kasur Cikini adalah kesetaraan sih biasanya tidak pernah membeda-bedakan anak. Meskipun dengan anak yang berkebutuhan khusus (ABK) semua sama tidak ada yang dibedakan. Cara mengajar dan perlakuannya pun setara tidak dibeda-bedakan. Serta menciptakan komunikasi yang setara dengan anak, dengan suasana yang akrab seperti teman dan berusaha menjadi idola anak.

Dari beberapa pernyataan di atas, secara keseluruhan peneliti mengambil kesimpulan bahwa kelima sikap positif yang dijabarkan seperti yang dikemukakan oleh Devito telah mendukung komunikasi interpersonal yang terjadi pada kedua pihak yang menjalin komunikasi yakni guru dan murid TK Mini Pak Kasur Cikini. Komunikasinya juga menghasilkan hubungan interpersonal yang efektif. Kelima sikap positif diatas telah mendorong sikap saling pengertian, saling menghargai dan saling mengembangkan kualitas hubungan interpersonalnya. 


\section{Peran Guru Membangun Perilaku Etis}

Etika mempelajari perilaku manusia yang dilihat dari baik dan buruknya secara universal. Selain itu etika juga menguji apakah etiket dan dan moral itu benar-benar baik atau tidak. Perilaku etis merupakan inti dari etika, etis berarti sesuai dengan aturan atau standar perilaku yang benar oleh karena itu perilaku etis perlu ditanamkan sejak dini untuk membentuk karakter yang santun dan sopan pada anak. Perilaku etis yang dimaksud peneliti di sini yaitu bagaimana anak menghormati orang yang lebih tua, menghormati lambang negaranya, berperilaku sopan, berbicara yang santun, berpakaian yang sopan, membuang sampah pada tempatnya, berkarakter positif serta mampu bergaul dengan baik di lingkungannya.

Di sini peneliti menggunakan pandangan Eudemonisme karena penelitian ini sesuai dengan pandangan yang dikemukakan Aristoteles yakni setiap kegiatannya manusia mengejar suatu tujuan untuk mencapai sesuatu yang baik. Pada penelitian ini tujuan yang akan dicapai guru TK Mini Pak Kasur Cikini adalah untuk membangun perilaku etis yang disebutkan di atas tadi kepada murid. Guru merupakan faktor utama dalam keseluruhan proses pendidikan. Di sekolah guru memiliki peran sebagai orang tua bagi anak didiknya. Guru harus mampu mencontohkan perilaku-perilaku baik dan menjadi teladan serta cerminan untuk anak. Anak pada usia dini selalu meniru apa yang dilihatnya. Oleh karena itu, melalui peranannya, diharapkan guru mampu mengubah sikap dan perilaku muridnya agar memiliki perilaku etis.

Menurut salah satu orang tua murid di TK Mini Pak Kasur Cikini, peran guru itu seperti membantu peran orang tua di sekolah. Mendidik anak, memberikan infomasi dan pengetahuan akademis serta membentuk karakter pada anak. Guru juga berperan sebagai model dan teladan bagi anak. Mencontohkan perilaku baik, mengajarkan sopan santun dan tata karma yang baik juga. Sedangkan menurut Kepala Sekolah TK Mini Pak Kasur Cikini mengatakan mampu menempatkan diri, berperilaku serta bertutur kata baik sebagai cerminan dan teladan untuk anak yang nyata dilihat. Sebagai role model untuk anak guru juga berperan untuk mencontohkan mana perilaku yang baik dan mana perilaku yang buruk yang dapat ditiru anak dalam kehidupan sehari-harinya. Peran guru yang seperti itulah yang mampu membangun perilaku etis pada anak.

Dalam membangun perilaku etis, peran guru di sini adalah lebih kepada memperbaiki kebiasaan yang salah dan mencontohkan perilaku yang dianggap baik dan beretika kepada anak dalam keseharian. Karena masih dalam usia yang masih dini jadi anak akan selalu meniru apa yang dilihat dan dicontohkan. Untuk itu guru juga harus berperilaku yang mencerminkan kepribadian yang berbudi pekerti baik. Hanya itu saja peran dari guru untuk membangun perilaku etis pada anak.

\section{Model Komunikasi Berlo}

Dari hasil wawancara peneliti dengan sejumlah narasumber maka hasil penelitian ini akan disusun menggunakan pendekatan model komunikasi Berlo. Dimana pendekatan model komunikasi Berlo ini memiliki empat unsur yakni Source (sumber) pihak yang menciptakan pesan, Message (pesan) terjemahan gagasan ke dalam kode simbolik, Channel (saluran) 
medium yang digunakan dalam membawa pesan, Receiver (penerima) orang yang menjadi sasaran komunikasi (Mulyana, 2012, p.162).

Source (Sumber), dalam model komunikasi Berlo, guru merupakan sumber yang menciptakan, menerjemahkan dan menyampaikan pesan untuk kebutuhan berkomunikasi. Kebutuhan ini berupa keinginan untuk mempengaruhi sikap dan tingkah laku orang lain. Guru sebagai sumber harus memperhatikan hal-hal berikut dalam berkomunikasi yakni pertama, keterampilan berkomunikasi, untuk membuat situasi dan kondisi kelas yang kondusif dan efektif saat kegiatan belajar mengajar berlangsung, seorang guru harus memiliki kemampuan untuk berkomunikasi dengan anak didiknya. Kemampuan dalam menyusun tujuan komunikasi ataupun menerjemahkan pesan ke dalam bentuk signal atau ekspresi tertentu. Untuk mengutarakan isi pesan dan merangsang anak agar berani mengatakan serta mengutarakan pendapatnya guru harus memiliki keterampilan seperti bercakap-cakap dan mampu berkomunikasi langsung (face to face) dengan anak.

Dalam KBM guru harus terampil membangun komunikasi dengan anak. Saat guru menyampaikan tema pembelajaran hari itu, guru harus mampu berdialog dan mengajak anak untuk mengikuti tema yang disampaikan guru. Misalnya saat itu temanya tentang profesi, guru harus bisa mengajak anak didiknya untuk bisa menggambarkan serta menjelaskan apa saja profesi itu selain itu harus mampu berdialog dan membuka percakapan langsung dengan anak mengenai bermacam-macam profesi yang ada. Kedua, sikap, sikap yang ditunjukan guru kepada anak didiknya adalah sikap yang dapat menjadi panutan dan dapat dicontoh anak karena sikap atau perilaku guru merupakan cerminan untuk anak didiknya. Sebagai salah satu panutan bagi anak, guru harus memiliki sikap professional, mau mengajar dan mampu memahami karakter anak. Memposisikan tubuh sejajar dengan anak agar anak merasa dekat dengan guru. Kemudian berbicara sopan dengan menggunakan bahasa Indonesia yang baik dan benar atau lebih kepada bahasa ibu agar anak mudah memahami apa yang guru sampaikan. Hal tersebut merupakan salah satu sikap yang ditunjukan guru dalam berkomunikasi dengan anak didiknya.

Ketiga, pengetahuan, seorang guru harus mampu menguasai topik yang akan disampaikan kepada anak didiknya. Sebagai fasilitator kemampuan guru dalam menyampaikan informasi dan pengetahuan diperlukan agar metode pembelajaran lebih kreatif serta tidak terpaku pada satu metode saja atau monoton. Tak hanya itu kemampuan memahami karakteristik anak juga dibutuhkan oleh seorang guru agar pesan, informasi atau pengetahuan tersalurkan dan dapat diterima anak dengan baik. Dalam penyampaian pesan guru selalu menyesuaikan dengan berbagai karakter anak yang berbeda-beda dan melihat bagaimana kondisi anak saat itu sehingga guru harus mampu merayu anak serta berusaha menjadi idola anak agar anak mudah terpersuasi.

Keempat, sistem sosial dan budaya, dalam membangun perilaku etis biasanya guru mencontohkan langsung perilaku-perilaku etis seperti berperilaku sopan dan menghormati orang yang lebih tua dan sesamanya, berbicara yang santun, berpakaian yang sopan. Tentunya dalam mencontohkan perilaku tersebut guru lebih berpatokan dan menerapkan perilaku etis yang sesuai dengan adat ketimuran dan budaya bangsa Indonesia sendiri. Guru di TK Mini Pak 
Kasur Cikini memiliki keterampilan komunikasi yang cukup baik serta mampu berkomunikasi baik verbal maupun nonverbal dengan anak didiknya.

Dengan sikap dan pengetahuan yang dimilikinya sudah menunjang sikap professional seorang guru dalam berkomunikasi dengan anak didiknya sendiri. Selain itu guru juga menerapkan adat ketimuran dan budaya bangsa Indonesia yang universal dalam berkomunikasi dengan anak didiknya. Tujuannya adalah agar anak memahami pesan apa yang disampaikan guru serta menghindari perbedaan antara guru dan anak didik yang dapat membuat anak merasa lebih dekat dengan gurunya.

Message (Pesan), mengajarkan atau membangun perilaku etis pada anak adalah message (pesan) yang akan disampaikan oleh guru. Perilaku etis yang dimaksud yaitu menghormati orang yang lebih tua, menghormati lambang negaranya, berperilaku sopan, berbicara yang santun, berpakaian yang sopan, membuang sampah pada tempatnya, berkarakter positif serta mampu bergaul dengan baik di lingkungannya. Pesan tersebut disampaikan setiap hari dan terus menerus agar bisa menjadi suatu kebiasaan pada diri anak. Pesan ini juga bersifat informatif, edukatif dan mempersuasi anak untuk berperilaku etis. Penggunaan bahasa dalam penyampaian pesan adalah dengan menggunakan bahasa Indonesia. Untuk menjadikannya sederhana dan mudah dipahami anak guru biasanya menggunakan bahasa ibu.

Guru TK Mini Pak Kasur Cikini menerangkan bahwa bahasa yang digunakan sehari-hari dalam penyampaian pesan saat KBM atau berkomunikasi dengan anak didik adalah bahasa Indonesia dan lebih kepada bahasa ibu yang lebih sederhana agar anak mengerti apa yang guru sampaikan. Struktur pesan biasanya dimulai dari pembuka hingga penutup atau evaluasi. Di TK Mini Pak Kasur Cikini sendiri kurikulumnya mengikuti kurikulum nasional ke 13 dengan panduan ajaran "ala" Pak Kasur yang kegiatan KBM dimulai dengan salaman dengan guru yang bertujuan untuk menanamkan perilaku menghargai dan menghormati orang yang lebih tua, baris berbaris dan upacara anak-anak dibiasakan hormat kepada bendera merah putih sebagai tanda menghargai lambang negaranya, menimbulkan rasa nasionalis pada anak sejak dini serta untuk melatih kedisiplinan dan kerapihan lalu kemudian masuk ke kelas dan langsung kepada inti pembelajaran (yang disesuaikan tema pada hari itu) kemudian ditutup dengan evaluasi. Biasanya sebelum dan sesudah KBM guru selalu membiasakan anak berdoa terlebih dahulu agar anak memiliki kepercayaan dan ketaatan kepada Tuhan-Nya masing-masing.

Dalam membangun perilaku etis pada anak isi pesan dapat diterjemahkan dalam bentuk komunikasi verbal dan nonverbal yang dapat dimengerti oleh anak. Melalui komunikasi dengan kata-kata (yang baik dan yang tidak baik), dengan memperlihatkan wajah (tatap muka), dengan tindakan (sentuhan) yang dapat dipraktikan langsung ke anaknya, serta alat peraga edukatif (APE), gambar atau warna, permainan, nyanyian atau lagu, dongeng atau cerita yang membantu menafsirkan isi pesan yang disampaikan (Latif et al., 2013, p.139).

Untuk mengekspresikan maksud dari isi pesan yang disampaikan guru biasanya guru menggunakan komunikasi verbal dan non verbal melalui alat peraga atau mencontohkan langsung. Metode pembelajaran yang digunakan adalah dengan bercakap-cakap, tanya jawab 
atau melalui nyanyian dan permainan yang disesuaikan dengan tema belajar saat itu. Selain itu untuk terciptanya keselarasan makna dari pesan yang disampaikan guru, guru harus mengetahui terlebih dahulu karakter anak didiknya masing-masing kemudian modal lainnya yaitu harus pandai merayu anak dan memiliki ide dalam membangun komunikasi melalui karakter anak yang berbeda-beda tersebut. Untuk menjaga hubungan interpersonal yang harmonis, guru selalu memposisikan dirinya sebagai ibu dan menunjukan kesejajaran yakni sebagai teman agar tidak ditakuti atau disegani anak didiknya selain itu untuk membuat anak didiknya tersebut merasa dekat serta diperhatikan oleh gurunya.

Channel (Saluran), saluran yang digunakan untuk menyampaikan tujuan pesan dari guru yaitu melalui alat peraga, gambar atau warna, permainan, nyanyian atau lagu, dongeng atau cerita dan tatap muka serta sentuhan. Dengan cara yang sederhana yaitu melalui nyanyian seperti lagu "Hormat Bendera" yang diciptakan oleh Pak Kasur sendiri. Lagu ini wajib dinyanyikan oleh murid-murid TK Mini Pak Kasur ketika upacara sebelum mereka masuk ke kelas. Lirik pada lagu ini mengajarkan anak-anak untuk menghormati dan menghargai lambing negaranya serta menanamkan rasa nasionalis kepada anak.

Lagu "Keranjang Sampah" dengan lirik : "Jika kau makan pisang, jangan dengan kulitnya, kulit dilempar keranjang, keranjang sampah namanya, jika ku makan pisang, tidak dengan kulitnya, kulit ku lempar keranjang, keranjang sampah namanya”.dari liriknya lagu ini mengajarkan anak untuk selalu membuang sampah pada tempatnya. Kemudian lagu "Sayang Semua" selalu diajarkan guru maupun orang tua agar anak menyayangi sesamanya.

Isi dan inti dari lagu yang diciptakan oleh Alm. Pak Kasur adalah mengajak anak-anak untuk bermain sambil belajar contoh kalimat mengajak seperti ayo, lihat, siapa . Melalui nyanyian, seorang anak akan lebih cepat menangkap apa yang mereka pelajari tanpa merasa adanya paksaan. Selain melalui nyanyian, guru juga membuat suatu permainan dalam menyampaikan suatu pesan. Permainan seperti berebut bangku atau lingkaran yang melatih kecepatan anak. Guru menyediakan bangku 10 sedangkan jumlah anak ada 12, bagi anak yang tidak mendapat bangku dapat kita katakan kalah karena bangkunya sudah habis guru kemudian memberitahu langsung face to face ke anak yang kalah tersebut bahwa untuk tidak berkecil hati, harus berani menerima kekalahan dengan lapang dada. Dan bagi yang mendapat bangku tidak boleh angkuh dan sombong karena seseorang tidak selamanya menang terus. Dari hal kecil seperti itulah yang mampu membangun perilaku anak agar bersikap supportif.

Guru TK Mini Pak Kasur Cikini berpendapat bahwa gambar juga dapat dijadikan sebagai media untuk menyampaikan pesan ke anak. Dengan gambar anak mampu melihat sendiri dan membandingkan mana yang baik dan mana yang buruk. Misal guru mencontohkan untuk berpakaian yang rapih, sopan dan beratribut lengkap saat ke sekolah, kemudian guru memperlihatkan gambar pertama yaitu seorang anak yang berpakaian rapih, berseragam lengkap lalu gambar kedua yakni seorang anak yang seragamnya tidak lengkap atau tidak memakai topi atau dasi. Dari gambar yang ditampilkan guru itu anak bisa membandingkan gambar yang mana yang harus dicontohnya. Di sisi lain guru juga memberitahukan kepada 
anak didiknya bahwa gambar pertamalah yang harus kalian tiru, pergi ke sekolah menggunakan seragam lengkap karena berpakaian yang rapih merupakan cerminan kepribadian seseorang.

Selain itu penyampaian pesan dapat melalui alat peraga. Biasanya guru menyediakan APE (Alat Peraga Edukatif) untuk merepresentasikan makna dari pesan yang akan disampaikan ke anak. Alat peraga seperti peraga rambu-rambu lalu lintas, papan geometri, puzzle profesi, puzzle hewan, puzzle buah-buahan, puzzle sayuran, papan huruf dan angka dan lainnya. Melalui alat peraga guru dapat pula mengekspresikan makna pesan yang akan disampaikan. Selain untuk mempermudah anak memahami apa maksud pesan tersebut, alat peraga juga mendukung guru dalam mencontohkan secara visual.

Secara face to face mencontohkan langsung kepada anak dalam kehidupan sehari-hari yang nyata terlihat dapat pula menjadi salah satu pilihan guru sebagai saluran komunikasi yang akan digunakan. Anak pada usia dini mudah meniru apa yang dicontohkan orang lain. Oleh karenanya melalui contoh sederhana yang dilakukan sehari-hari saja dapat menjadikan suatu rangsangan bagi anak untuk berperilaku sesuai yang dicontohkan guru. Di sini guru dapat menafsirkan pesannya melalui verbal dan nonverbal. Dengan menggunakan pilihan kata-kata yang tepat dan mengorganisasikan pesan secara sistematis serta ekspresi wajah yang sesuai akan mempengaruhi murid dalam menerima dan memaknai pesan tersebut.

Receiver (Penerima) dari hasil wawancara data dengan Kepala Sekolah TK Mini Pak Kasur, diketahui bahwa penerima pesan yang disampaikan guru adalah anak didiknya sendiri (murid TK Mini Pak Kasur Cikini). Dimana penerima pesan masih pada usia dini yakni antara 2-6 tahun. Setelah melakukan komunikasi dengan gurunya, murid memiliki suatu kewajiban untuk meyakinkan dirinya sendiri bahwa ia telah menerima dan memahami pesan yang telah disampaikan guru. Anita Taylor (dalam Rakhmat, 2004, p.131) menjelaskan menerima adalah sikap yang melihat orang lain sebagai individu yang patut dihargai ketika ia menguraikan peranan "percaya" dalam komunikasi interpersonal. Murid menganggap gurunya tersebut sebagai sumber yang terpercaya, sehingga ia menerima apa yang guru sampaikan.

Kemampuan mendengarkan juga sangat penting dimiliki murid. Seperti yang dikatakan Stewart L. Tubbs dan Sylvia Moss yang diterjemahkan oleh Deddy Mulyana dan Gembirasari (dalam Aw, 2011, p.106) mendengarkan adalah suatu proses yang rumit, yang melibatkan empat unsur yakni, Pertama, mendengar, telinga secara otomatis akan menangkap stimuli berupa segala suara tanpa diperintah. Pada unsur ini murid mendengar dengan sendirinya melalui indera pendengarnya tanpa perintah suara guru menjelaskan pesan yang akan disampaikan. Kedua, memperhatikan, secara sengaja memusatkan perhatian dan kesadaran kita pada stimuli tertentu dan mengabaikan stimuli yang lainnya. Saat KBM murid mendengar banyak suara di kelas namun karena ia memusatkan perhatiannya hanya kepada guru maka ia hanya fokus mendengarkan apa yang guru sampaikan.

Ketiga, memahami, suatu proses pemberian makna yang kita dengar, yang sesuai dengan makna yang dimaksudkan pengirim pesan. Setelah mendengar dan memperhatikan apa yang guru sampaikan baik verbal maupun nonverbal, melalui berbagai saluran komunikasi, murid 
harus mampu memahami makna dan stimuli yang diberikan guru. Setelah ia mampu memahaminya berarti ia sudah dapat mendengarkan dengan baik. Keempat, mengingat, mengingat adalah proses menyimpan informasi ke dalam memori. Dengan demikian setelah murid mendengar, memperhatikan dan memahami makna yang disampaikan guru dengan baik maka sebagian stimuli simbol, kata, ataupun syair dari nyanyian itu akan tersimpan di memorinya.

Oleh karena itu unsur-unsur yang telah dijabarkan peneliti sebelumnya yakni dengan mendengarkan apa yang disampaikan guru, murid dapat mengolah secara komprehensif semua stimuli dan pesan yang ia terima sampai ia dapat memahami dan mengingat dengan cermat pesan apa yang disampaikan oleh gurunya kemudian karena pesan tersebut telah disimpan dimemorinya maka anak akan melakukan apa yang guru sampaikan itu tanpa paksaan dan apabila dilakukan secara terus menerus itu akan menjadi suatu kebiasaan pada anak tersebut.

Tabel 1. Hasil Diskusi

$\begin{array}{lll}\text { Teori } & \text { Pertanyaan } & \text { Temuan } \\ \text { Source } & \begin{array}{l}\text { Siapa yang } \\ \text { menciptakan pesan? }\end{array} & \begin{array}{l}\text { Guru sebagai komunikator yang melakukan } \\ \text { komunikasi interpersonal atau menciptakan } \\ \text { pesan. }\end{array} \\ \text { Message } & \begin{array}{l}\text { Pesan apa yang akan } \\ \text { disampaikan oleh } \\ \text { sumber? }\end{array} & \begin{array}{l}\text { Pesan yang disampaikan oleh guru yaitu } \\ \text { untuk membangun perilaku etis. Tujuannya } \\ \text { untuk mempengaruhi sikap dan tingkah laku } \\ \text { anak agar menghormati orang yang lebih tua, } \\ \text { menghormati lambang negaranya, berperilaku } \\ \text { sopan, berbicara yang santun, berpakaian } \\ \text { yang sopan, membuang sampah pada } \\ \text { tempatnya, berkarakter positif serta mampu } \\ \text { bergaul dengan baik di lingkungannya. }\end{array} \\ & & \end{array}$

Channel Saluran yang digunakan

Saluran komunikasi yang digunakan yaitu dalam penyampaian melalui nyanyian, permainan, gambar, alat pesan tersebut? peraga dan mencontohkan langsung kepada anaknya dalam kehidupan sehari-hari yang nyata dilihat.

Receiver Ditujukan kepada siapa
pesan tersebut?

Kepada murid TK Mini Pak Kasur Cikini yang berusia dini yaitu 2-6 tahun. Anak pada usia tersebut memiliki sikap mudah meniru apa yang dicontohkan orang lain. 
Dari hasil analisis diketahui bahwa peran guru sangat mempengaruhi murid TK Mini Pak Kasur Cikini dalam berperilaku etis. Salah satu orang tua murid mengatakan bahwa guru di TK Mini Pak Kasur telah membantu peran orang tua dalam mengajarkan anaknya berperilaku baik. Anak saya sudah dapat menjawab dan menerima telepon masuk dengan tutur bahasa yang sopan, mengingatkan saya dan suami untuk mencuci tangan dan berdoa terlebih dahulu sebelum makan. Adanya perubahan perilaku pada anaknya. Sekarang anaknya selalu memberi salam ketika keluar dan masuk rumah, lebih ramah dengan orang sekitar, sering bergaul bahkan sering membela temannya yang dibully. Untuk akademisnya, anaknya memiliki minat belajar yang bagus, selalu ingin tahu segala sesuatu yang baru, lebih terbuka dalam bercerita, dan menjadi berani tampil dipublik tidak pemalu lagi.

Dalam membangun perilaku etis pada anak, guru melihat keefektifan komunikasi interpersonalnya melalui keterbukaan, empati, sikap mendukung, sikap positif dan kesetaraan. Dari semua saluran komunikasi yang dipergunakan ternyata semuanya mendukung dan memfasilitasi guru dalam penyampaian pesan. Sehingga komunikasi interpersonal antara guru dan murid dapat dikatakan efektif untuk mempengaruhi murid berperilaku etis. Dari hasil analisis data dengan pendekatan model komunikasi Berlo diketahui juga bahwa melalui perannya guru telah berhasil mempengaruhi muridnya untuk berperilaku etis. Hal ini terbukti dari salah satu orang tua murid yang anaknya telah memiliki perilaku etis dimana anaknya meniru apa yang guru ajarkan dan telah menjadi kebiasaan karena dilakukan setiap hari dan terus menerus.

\section{SIMPULAN}

Adapun kesimpulan yang diperoleh dari hasil penelitian mengenai Peran Guru Membangun Perilaku Etis Dalam Komunikasi Interpersonal Pada Murid Taman Kanak-Kanak Mini Pak Kasur Cikini adalah sebagai berikut :

1. Peran guru sangat mempengaruhi murid dalam berperilaku etis. Melalui peranan guru, orang tua juga merasa sangat terbantu dalam mengajarkan perilaku etis pada anaknya.

2. Adanya perubahan perilaku pada murid. Hal tersebut dapat dilihat dari komunikasi interpersonal yang terjalin secara efektif antara guru dan murid.

3. Kelima sikap positif yang ditunjukan guru yakni keterbukaan, empati, sikap mendukung, sikap positif dan kesetaraan telah mendukung komunikasi interpersonal yang terjadi pada kedua pihak (guru dan murid) yang menjalin komunikasi. 


\section{DAFTAR PUSTAKA}

Aw, S. (2011). Komunikasi Interpersonal. Yogyakarta: Graha Ilmu.

Bertens, K. (2015). Etika. Yogyakarta: Kanisius.

Effendy, O. U. (2011). Ilmu Komunikasi Teori dan Praktek. Bandung: PT Remaja Rosdakarya Offset.

Hardjana, A. M. (2003). Komunikasi Intrapersonal \& Interpersonal. Yogyakarta: Kanisius.

Latif, M., Zulkhairina., Zubaidah, R., \& Afandi, M. (2013). Orientasi Baru

Pendidikan Anak Usia Dini Teori Dan Aplikasi. Jakarta: Kencana Prenada Media Group.

Mulyana, D. (2012). Ilmu Komunikasi Sebagai Suatu Pengantar. Bandung: PT Remaja Rosdakarya.

Rakhmat, J. (2004). Psikologi Komunikasi. Bandung: PT Remaja Rosdakarya.

Sugiyono. (2015). Memahami Penelitian Kualitatif. Bandung: Alfabeta 